\title{
PUTUSAN-PUTUSAN MAHKAMAH AGUNG YANG "BERTENTANGAN" DENGAN NASH
}

\author{
Rahmat Yudistiawan \\ Fakultas Syariah dan Hukum UIN Sunan Kalijaga, Yogyakarta, Indonesia \\ rahmatyudistiawan@yahoo.com
}

\begin{abstract}
This study aimed to analyze the rulings of the Supreme Court No. 51 K/AG/1999 and $120 \mathrm{~K} / A G / 2005$ about the case of a non-muslim heirs and inheritance for a wedding without license that for the author though same areas of inheritance but it is not easy to find solutions and formulation (legal formation method) in Nash, even it was decided through ruling of law any one decided "conflicted" with Nash. Through method of ijtihad Fiqh Indonesia by dividing it into two invalid constructs of thought, i.e. Urf Indonesia as his Grand Thoery and Fiqh Mazhab Negara as Aplicative Theory. The author's analysis of the results shows that both ruling of law in accordance with invalid constructs of think in Fiqh Indonesia, such as the case of the non-muslim heirs that get right with wasiat wajibah method, not apart on the issue of human rights system and the principle of the plurality of life of the nation which Indonesia's pilar bhineka tunggal ika, and the case of inheritance from marriage without license it was discovered that the wedding deed/certificate be decisive of wedding in Indonesia as a means of authentic evidence in determining the identity of the wedding.
\end{abstract}

Keywords: Fiqh of Indonesia, non-Muslim heirs, Marriage Registration

\begin{abstract}
Abstrak. Penelitian ini ditujukan untuk menganalisa putusan-putusan Mahkamah Agung No. 51 K/AG/1999 dan 120 K/AG/2005 tentang kasus ahli waris non-muslim dan hak waris bagi pernikahan yang tidak dicatat yang bagi penulis walau sama-sama membahas tema waris namun tidaklah mudah mencari solusi dan formulasinya dalam Nash, bahkan setelah diputuskannya pun terkesan "bertentangan" dengan Nash. Melalui metode ijtihad Fiqh Indonesia dengan membaginya menjadi dua konstruk berpikir, yaitu Urf Indonesia sebagai Grand Thoery-nya dan Fiqh Mazhab Negara sebagai Aplicative Theory-nya. Dari hasil analisa penulis menunjukkan bahwa kedua putusan tersebut sesuai dengan konstruk berpikir Fiqh Indonesia, seperti kasus ahli waris non-muslim yang mendapatkan haknya melalui jalur wasiat wajibah, tidak terlepas pada isu HAM dan prinsip pluralitas kehidupan bangsa Indonesia yang bhineka tunggal ika, dan kasus hak waris dari pernikahan yang tidak dicatatkan ditemukan bahwa pencatatan pernikahan menjadi penentu (rukun) berlangsungnya pernikahan di Indonesia sebagai alat bukti yang autentik dalam menetapkan identitas pernikahan.
\end{abstract}

Kata Kunci: Fiqh Indonesia, Ahli Waris Non-Muslim, Pencatatan Pernikahan 


\section{Pendahuluan}

Perubahan sosial merupakan salah satu faktor munculnya konflik sosial yang terdiri dari masalah-masalah baru. Hal ini sesuai dengan apa yang dinyatakan Ian Robertson seorang sosiolog dari University of California Los Angeles "Social Change is The alteration of patterns of culture, Social structure and Social behaviours overtimes" perubahan sosial ialah perubahan pola budaya dalam masyarakat, struktur sosial dan perilaku masyarakat yang terjadi setiap waktu.

Adapun yang mempengaruhi perubahan sosial itu terjadi disebabkan karena adanya faktor persinggungan budaya antara wilayah baik secara nasional maupun internasional, perkembangan teknologi, ide-ide baru (ideologi) dan hal lain sebagainya. Permasalahan-permasalahan baru tersebut pada akhirnya harus dicarikan dan ditemukan solusi atau pemecahannya demi sebuah kemaslahatan.

Islam sebagai agama yang memiliki pengikut terbesar pun pada akhirnya akan mendapati dan menghadapi permasalahanpermasalahan tersebut, akan tetapi sejak jauh-jauh hari Allah SWT telah menjelaskan di dalam al-Qur'an agar dapat mengembalikan semua permasalahan yang ada kepada Allah, Rasul-Nya dan Ulil Amri (Pemimpin), sebagaimana firman-Nya:

"Hai orang-orang yang beriman, ta 'atilah Allah dan ta 'atilah Rasul (Nya), dan ulil amri di antara kamu. Kemudian jika kamu berlainan pendapat tentang sesuatu, maka kembalikanlah ia kepada Allah (Al-Qur'an) dan Rasul (sunnahnya), jika kamu benar-benar beriman kepada

1 Departemen Agama RI, Al-Quran dan Terjemahnya, (Semarang: PT.Karya Toha Putra, 1998), h. 162.
Allah dan hari kemudian. Yang demikian itu lebih utama (bagimu) dan lebih baik akibatnya". (QS. An-Nisa' : 59) ${ }^{1}$

Kadang kala dari berbagai permasalahan kekinian yang sering terjadi di lingkungan, tidak semudah mencari solusi melalui penelusuran aturan ketika dihadapkan kasus-kasus global yang semakin kompleks.

Hal itu biasanya merupakan kasus baru bagi umat ketika ia dibenturkan dengan aturan yang ada lalu terkesan tidak memberikan jawaban pasti, sehingga dengan serta-merta dihadapi dengan penentangan dan justifikasi berdasarkan sikap dan perilaku yang salah akhirnya membawa masyarakat menjadi kaku dan kolot dengan menjauh dari perkembangan yang ada, padahal solusi yang tepat amat dibutuhkan.

Masalah ekonomi, kepentingan, kesenjangan sosial dan lain sebagainya itu semua tidak mudah dihadapi, semudah membalikkan telapak tangan permasalahan menjadi terselesaikan. Di sinilah peran penting ulama dan umaro (pemerintah) dengan melahirkan solusi dari berbagai kejadian akibat perubahan sosial dan perkembangan zaman di setiap lini kehidupan. Karena sebagaimana Imam Ghazali mengatakan "Agama jika di topang dengan kekuasaan akan kuat dan kekuasaan jika ditopang oleh agama akan kekal."

Sedikit flash back tentang sejarah perkembangan hukum pada masa pemerintahan Islam ketika menghadapi permasalahan dan perubahan zaman. Khulafa' al-Rasyidin adalah penafsir hukum pertama, semua ijtihad di bawah payung nilai dan norma al-Quran dan Sunnah dengan pemahaman dan pertimbangan yang kontekstual. 
Semasa mereka banyak kontribusi besar dalam evolusi pemikiran hukum Islam yang dapat dipetakan dalam tiga hal, yaitu; (1) meneruskan pemerintahan Rasulullah saw dalam bidang politik dan luar negeri; (2) berhasil mengaplikasikan ajaran Islam dalam kehidupan (dakwah bil fi'li dan dakwah bil qauli); (3) berhasil menciptakan konsep pola pemikiran hukum dan panduan memahami ajaran Islam ketika berhadapan dengan tantangan dan perubahan zaman.

Hukum Islam atau fiqh pada masa ini muncul dengan satu corak sendiri dalam dunia hukum yang pernah dikenal manusia, karena tidak hanya sekedar isi dari al-Quran dan Sunnah, tetapi meluas kepada aturan dan pemikiran umat Islam yang setia dengan tuntunan alQuran dan Sunnah.

Hukum Islam tidak hanya yang ditentukan dalam catatan sejarah, tetapi juga mungkin untuk berkembang selama umat Islam masih ada. Segala persoalan sosial yang berkaitan dengan masyarakat muslim dan diberikan aturannya dengan nilai-nilai keislaman, maka aturan tersebut adalah hukum Islam, sehingga hukum ini tidak lagi sebagai identitas agama saja, tetapi juga identitas manusia. $^{2}$

Akhirnya dalam sejarah perkembangan fiqh selanjutnya, dikenallah istilah baru yaitu fiqh Irak, fiqh Madinah, fiqh Syam dan fiqh Maghrib. Ada pula fiqh ahl ra'yi dan fiqh ahli hadits, dan yang lebih menggaung dan terkenal di telinga masyarakat saat ini yaitu adanya fiqh Hanafi (w. 150H), fiqh Maliki (w. 179H), fiqh Syafi'i (w. 204H) dan fiqh Hanbali (241H).

2 Abdul Karim Munthe, Hukum Islam dan Perubahan Masyarakat, diakses pada tanggal 29 Januari 2014 dari http://abdulkarim munthe.blogspot.com/2013/02/hukum islam dan perubahan masyarakat.
Di Indonesia pun, sejak pertama Islam masuk telah dikenalkan berbagai aliran pemikiran fiqh yang lahir dan berkembang di Indonesia. Ada pemikiran Syekh Abdurrauf Singkel (1643-1693M), Syekh Arsyad al-Banjari, Syekh Ahmad Khatib al-Minangkabau, Syekh Nawawi Banten (1230H/1813M1314H/1897M), KH. Hasyim Asy'ari (1871-1947M), KH. Ahmad Dahlan dan banyak lagi yang lain.

Beberapa pemikir hukum kontemporer yang tercatat memberi andil besar pada perkembangan aturan hukum di Indonesia dikenal dengan fiqh Indonesianya, adalah TM. Hasbi ashShiddieqi (1905-1975) yang selanjutnya akan menjadi salah satu tolak ukur dalam penelitian ini melihat filosofi dan sejarah aturan hukum Islam yang telah dikodifikasi dan dilegitimasi tidak terlepas dari pemahaman teori fiqh Indonesia Hasbi. ${ }^{3}$

Perkembangan dan perubahan sosial adalah faktor penting lahirnya ijtihad, sebab pada saat terjadi permasalahan atau kasus baru yang berbeda tentunya akan memerlukan aturan. Lalu aturan yang seperti apa yang pantas dan sesuai bila permasalahan tersebut merupakan hal baru dalam Islam bahkan terkesan "bertentangan" dengan Nash al-Quran dan Hadis? Dan bagaimanakah cara menghadapinya?

Hal ini terjadi ketika Mahkamah Agung Indonesia pada tahun 1999 melahirkan putusan yang kontroversial. Dengan mengembangkan pemahaman Islam seorang ahli waris non-muslim yang secara aturan hukum tidak mendapatkan bagian dari harta

${ }^{3}$ Husein Muhammad, dkk., Dawrah Fiqh Concering Women-Modul Kursus Islam dan Gender, (Cirebon: Fahmina Institute, 2007) h. 257 
peninggalan kini mendapatkan haknya melalui jalur wasiat wajibah.

Padahal, secara tegas dalam aturan Islam jelas menyebutkan, yang menjadi penghalang seseorang mendapatkan bagian waris salah satunya disebabkan berlainan agama atau non-Islam(muslim). Sebagaimana sabda Rasulullah saw.: "Orang Islam tidak dapat mewarisi harta orang kafir dan orang kafir pun tidak dapat mewarisi harta orang Islam. (HR. Muttafaq Alaih)."

Kejadian ini akhirnya menjadi polemik yang terus diperdebatkan hingga saat ini di kalangan umat Islam, melihat hal tersebut menjadi dasar mula pengembangan aturan melalui pemahaman hakim ketika memutuskan perkara di bidang kewarisan Islam.

Pelbagai masalah terkait persoalan sipil sering kali didengar, dan hal ini menunjukkan bahwa terdapat permasalahan yang krusial di bidang tersebut. Selain dari masalah di atas, terdapat pula putusan Mahkamah Agung yang bagi penulis masih terasa mengganjal terutama soal harmonisasi dan sinkronisasi hukum serta rasa keadilan hakim yang patut untuk dipertanyakan.

Dalam bidang yang sama namun kasus yang berbeda ditemukan bahwa hak waris dari pernikahan yang tidak dicatatkan, terutama bagi anak dari hasil pernikahan tersebut diputuskan, ia tidak mendapatkan hak warisnya. Padahal, dalam hukum Islam hanya 3 macam penghalang mewarisi, yaitu; perbudakan, pembunuhan dan berlainan agama.

Sedangkan dalam KHI pasal 173 seorang terhalang menjadi ahli waris, apabila ia: a) membunuh dan menganiaya berat para pewaris, dan b) memfitnah pewaris melakukan kejahatan. Tidak ada satu pun aturan, baik dalam hukum Islam maupun positif yang menyatakan secara eksplisit bahwa gugurnya hak seseorang memusakai disebabkan karena perkawinannya tidak dicatatkan.

Kalaupun hal ini mengenai sahnya pernikahan tersebut, maka pencatatan pernikahan bukan bagian dari penentu sahnya pernikahan sebab dalam Fiqh (klasik) para ulama tidak menjadikan hal tersebut bagian dari rukun pernikahan.

Jika benar bahwa pilihan tindakan hakim adalah atas hasil pemaknaanpemaknaan yang dipersitegangkan antara nilai, norma, dan berbagai ide abstrak dengan situasi dan kondisi dalam rangka mencapai tujuan, maka yang sangat penting dipahami adalah apa pemaknaan-pemaknaan hakim terhadap putusan yang dibuatnya?

Tujuan-tujuan apakah yang ingin dicapai oleh hakim menjatuhkan putusan seperti yang digambarkan di atas? Bagaimana hakim memaknai wasiat wajibah bagi ahli waris non muslim dan pernikahan yang tidak dicatatkan menjadi salah satu penghalang waris?

Untuk itu, yang harus dipahami adalah bukan pada salah atau benarnya hakim menjatuhkan putusan, akan tetapi lebih kepada pertanyaan untuk mencari penjelasan mengapa hakim sampai menjatuhkan putusan seperti itu.

\section{Pembahasan Teoritik}

Fiqh adalah produk anak zaman yang lahir, tumbuh, dan berkembang sesuai dengan perkembangan zamannya pada kerangka ruang dan waktu yang mewadahinya. Fiqh berubah sesuai dengan perubahan sosial. Fiqh juga berbeda sesuai dengan perbedaan para pemikirnya, pembentuknya, dan pengembangannya dari satu waktu ke waktu lain, atau dari suatu tempat ke 
tempat lain. Tidak heran bila kemudian lahir sejumlah mazhab fiqh yang berbeda satu sama lain meskipun bersumber pada Al-Quran dan Hadis yang sama dan belajar dari guru yang sama, atau bahkan berbeda dengan gurunya sendiri. ${ }^{4}$

Bermula pada munculnya ide pemikiran tentang konsepsi dan formulasi pembentukan hukum Islam (figh) di abad XX, yang disebabkan atas masalah-masalah empirik dengan pengembangan pemikiran keislaman berupa kungkungan pola pikir para ulama yang fahm al-ilm li al-inqiyad ketika memahami doktrin hukum Islam yang terdapat di dalam khazanah literatur klasik (tsarwah fiqhiyyah) untuk menjawab problematika sosial, akhirnya membuat eksistensi hukum Islam tampak resisten, tidak mampu mematrik diri, dan sebagai konsekuensinya ia hadir bagai barang asing bagi persoalan sosial politik. Akibatnya, terbengkalainya sederet nomenklatur permasalahan sosialpolitik yang terjadi di masyarakat. ${ }^{5}$

Beberapa cara dan upaya untuk menginkorporasikan serta mempertimbangkan suatu unsur struktur kebudayaan (adat) ke dalam rumusan hukum Islam. Juga melihat kenyataan bahwa praktek hukum Islam masyarakat Indonesia juga begitu beragam (plural) sesuai dengan karakter, ideologi dan mazhab masingmasing individu dan kelompok, baik yang terorganisir ataupun tidak, baik yang sesuai dengan aturan hukum negara ataupun tidak.

Apalagi ketika melihat watak dasar fiqh (yang tidak boleh digantikan

4 Marzuki Wahid, Fiqh Indonesia; Kompilasi Hukum Islam dan Conter Legal Draft Kompilasi Hukum Islam dalam Bingkai Politik Hukum Indonesia, h. x-xi

5 Marzuki Wahid, Fiqh Indonesia, ,, h. xxxiii; Mahsun Fuad, Hukum Islam Indonesia; oleh sejarah) adalah adanya ketersediaan pilihan-pilihan hukum lebih dari satu ( $d z u$ wujuhin) dalam satu masalah sosial keagamaan. Maka dapat diyakini bahwa prinsip-prinsip hukum Islam memberikan ruang gerak yang lebar bagi pengembangan dan ijtihadijtihad baru serta dalam pilihan-pilihan hukum yang lebih dari satu ( $d z u$ wujuhin) dalam menghadapi suatu masalah sosial keagamaan. Dengan berpegang pada paradigma itu, dalam konteks pembangunan bangsa, bagi penulis itulah yang dimaksud dengan Fiqh Indonesia. ${ }^{6}$

Puncak pemikiran di atas sebenarnya terjadi pada tahun 1961, ketika dalam satu acara Dies Natalis IAIN Sunan Kalijaga yang pertama, Hasbi selaku penggagas teori Fiqh Indonesia memberikan makna dan definisinya secara cukup artikulatif. Dalam orasi ilmiahnya yang bertema "Syari'at Islam Menjawab Tantangan Zaman", Hasbi secara tegas mengatakan:

"Maksud untuk mempelajari syariat Islam di universitas-universitas Islam sekarang ini supaya fiqh atau syariat Islam dapat menampung seluruh kemaslahatan masyarakat dan dapat menjadi pendiri utama bagi perkembangan hukum-hukum di tanah air kita yang tercinta ini. Maksud kita supaya dapat menyusun suatu fiqh yang berkepribadian kita sendiri sebagaimana sarjana-sarjana Mesir sekarang ini sedang berusaha me-Mesir-kan fiqhnya.

Fiqh Indonesia ialah fiqh yang ditetapkan sesuai dengan kepribadian Indonesia, sesuai dengan tabi'at dan watak Indonesia.

Dari Nalar Partisipatoris Hingga Emansipatoris, (Yogyakarta: LKiS, 2005), h. 62 ${ }^{6}$ Mahsun Fuad, Hukum Islam Indonesia, h. 66 
Fiqh yang berkembang dalam masyarakat kita sekarang ini sebagiannya adalah fiqh Hijaz, fiqh yang terbentuk atas dasar adat istiadat dan 'urfyang berlaku di Hijaz, atau fiqh Mesir, yaitu fiqh yang telah terbentuk atas dasar adat istiadat dan kebiasaan Mesir, atau fiqh Hindi, yaitu fiqh yang terbentuk atas 'urf dan adat istiadat yang berlaku di India.

Selama ini, kita belum
menunjukkan kemampuan untuk
berijtihad, menujukkan hukum fiqh yang
sesuai dengan kepribadian Indonesia.
Karena itu kadang-kadang kita paksakan
fiqh Hijazi atau fiqh Misri atau fiqh Iraqi
berlaku di Indonesia atas dasar taklid"7

Pemikirannya tentang hukum yang dibangun dari sumber-sumber yang telah ada, sangatlah relevan dengan kondisi sosial Indonesia. Secara ringkas, dapat dipahami bahwa model berpikir Fiqh Indonesia sebenarnya mengarah kepada tipe kontekstualisasimazhabi responsi-simpatis partisipatoris.

Tipologi atas pemahaman ini telah dirumuskan oleh Mahsun Fuad dalam bukunya dengan mendasarkan pada fakta-fakta, Pertama, dalam hal upaya penemuan dan pengembangan hukum baru, secara cukup dominan pemahaman ini mengacu pada hasilhasil pemikiran dan penemuan hukum dari berbagai mazhab, yang disenergikan dengan kondisi dan situasi Indonesia sebagai objeknya.

Kontekstualisasi fiqh mazhab (klasik) ditempuh melalui metode komparasi semua mazhab hukum, hukum adat dan hukum positif, dibantu dengan pendekatan sosial-kultural historis. Dengan demikian, walaupun penafsiran secara langsung juga

\footnotetext{
${ }^{7}$ Mahsun Fuad, Hukum Islam Indonesia, h. $66-67$

${ }^{8}$ Mahsun Fuad, Hukum Islam Indonesia,, h. $244-245$
}

dilakukan dan dipakai, namun secara aplikatif tampak kurang begitu dominan sehingga pola penafsiran yang diterapkan adalah induksi-deduksi, dan hal tersebut terkesan tidak menampakkan pemaknaan baru secara signifikan. ${ }^{8}$

Kedua, dapat dilihat dari hasil ijtihad atau fatwa Hasbi yang cenderung menampakkan kesejajarannya dengan modernisasi-pembangunan, terutama ketika teori ini diambil menjadi pola kebijakan dan pembangunan resmi negara.

Hal ini terlihat pada dukungannya terhadap pengelolaan zakat secara penuh oleh negara, sebagai wujud nyata bagi upaya pencarian modal pembangunan nonpajak. Dalam domain yang lebih umum, pemikiran Hasbi tentang bolehnya jabat tangan laki-laki dengan perempuan, bisa dikatakan merupakan bagian awal dari upaya emansipasi perempuan dalam pembangunan. Maka dari itu, arah pemikiran semacam ini menjurus kepada pola upaya responsi-simpatis terhadap modernisasi-pembangunan. ${ }^{9}$

Ketiga, dilihat dari makna Fiqh Indonesia sebagai fiqh dengan kepribadian Indonesia, yang kelahirannya secara implisit diawali dengan adanya perdebatan dengan Soekarno tentang pentingnya peran ulama dalam memberi kontribusi signifikan bagi proses pembangunan (revolusi).

Hal ini sebenarnya merupakan konsekuensi logis dari dukungan atau responsi-simpatis-nya terhadap modernisasi-pembangunan. Justifikasi yang hampir sama terlihat dari munculnya KHI, yang oleh sementara

\footnotetext{
h. 245
} 
kalangan dianggap sebagai model atau representasi dari Fiqh Indonesia yang ia gagas. ${ }^{10}$

Oleh karena itu, tidak terlepas pula pada aturan-aturan hukum lainnya di Indonesia yang telah diterapkan sebagai aturan negara yang sah ${ }^{11}$, maka ia pun merupakan bagian dari model atau representasi dan manifestasi Fiqh Indonesia yang didasarkan kepada kepribadian bangsa Indonesia (saat ini) yang konstitusional dan demokratis.

Model Islam Indonesia

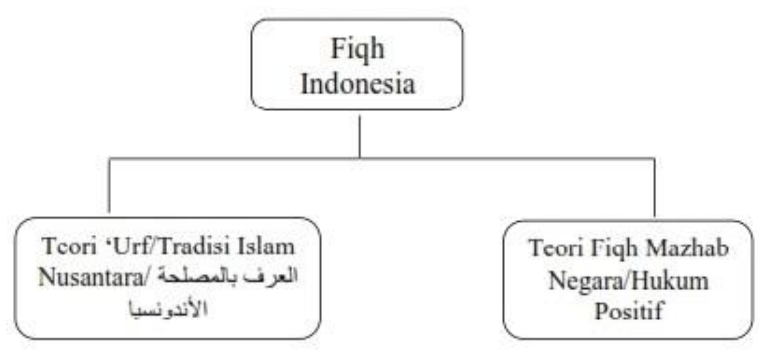

\section{Putusan Nomor 51 K/AG/1999 Tentang Ahli Waris Non Muslim}

Berawal dari pemikiran Ibn Hazm, maka muncul wasiat wajibah yaitu wasiat yang pelaksanaannya tidak dipengaruhi atau tidak tergantung kepada kemauan atau kehendak si pewasiat, akan tetapi penguasa atau hakim sebagai aparat negara mempunyai wewenang untuk memaksa atau memberikan putusan wasiat wajibah kepada kaum kerabat tertentu. Hal itu telah diputuskan oleh Mahkamah Agung Republik Indonesia dalam perkara No. $51 \mathrm{~K} / \mathrm{AG} / 1999$.

Wasiat wajibah yang diputuskan oleh Mahkamah Agung tersebut mengenai kasus saudara kandung non

\footnotetext{
10 Mahsun Fuad, Hukum Islam Indonesia,,, h. 245

11 Karena gagasan ini lahir di masa revolusi pembangunan terhadap pembentukan cita-cita negara, maka undang-undang yang disusun pun belum terlalu banyak yang dikodifikasi dan diterapkan sebagai aturan negara.
}

muslim. Padahal, wasiat wajibah dalam Kompilasi Hukum Islam dianalogikan kepada anak angkat dan orang tua angkat. ${ }^{12}$ Sedangkan perbedaan agama tetap merupakan salah satu penghalang untuk dapat saling mewarisi.

Dari data yang didapatkan berupa putusan kasasi, Mahkamah Agung memberikan wasiat wajibah kepada saudara kandung non muslim berdasarkan pemahaman Al-Quran surah al-Baqarah ayat 180: "Diwajibkan atas kamu, apabila seorang di antara kamu kedatangan maut, jika ia meninggalkan harta yang banyak, berwasiat untuk ibu-bapak dan karib kerabatnya secara ma'ruf, kewajiban atas orang-orang yang bertakwa"

Menurut Ibn Hazm, kewajiban ini ditujukan untuk ayah dan ibu (orang tua) dan karib kerabat terutama yang tidak dapat mewarisi apabila si pewaris sebelumnya tidak berwasiat. Pendapat inilah yang akhirnya jadi pertimbangan Mahkamah Agung dalam memberikan wasiat wajibah kepada saudara kandung non-muslim.

Pertimbangan lainnya untuk menjaga keutuhan keluarga dan mengakomodir adanya realitas sosial masyarakat Indonesia yang pluralitas yang terdiri dari berbagai etnis dan keyakinan. Serta kemaslahatan untuk memenuhi rasa keadilan. ${ }^{13}$

Bila ditelaah lebih lanjut melalui model berpikir Fiqh Indonesia berdasarkan pertimbangan tersebut apakah "bertentangan" dengan Nash? Terkait dengan boleh atau tidaknya ahli

12 Lihat KHI Pasal 209 tentang harta peninggalan bagi anak angkat dan orang tua angkat.

13 Sahriani, Thesis: Pembagian Harta Warisan Orang Yang Berbeda Agama Dalam Perspektif Hukum Islam (Studi Kasus Putusan Mahkamah Agung RI No. 51 K/AG/1999), (Sekolah Pascasarjana Universitas Sumatra Utara, Medan, 2009), h. 2 
waris non-Muslim menerima waris dari pewaris Muslim, ternyata para ulama berbeda pendapat.

Jumhur ulama berpendapat bahwa ahli waris Muslim tetap tidak dapat mewarisi pewaris non-Muslim begitu juga sebaliknya. Pendapat ini di dasarkan pada bunyi teks hadis yang disebutkan sebelumnya. Sedangkan pada pendapat yang berbeda, seperti Muadz bin Jabal, Muawiyah, Masruk (generasi sahabat) dan Ibnu Musayyab (generasi tabi'in) serta kalangan Syi'ah Imamiyah, mengemukakan bahwa pewaris Muslim dapat mewarisi ahli waris non-Muslim. ${ }^{14}$

Pendapat kalangan ini rupanya disimpulkan dari sebuah hadis lain yang menegasikan bahwa, "Islam itu tinggi dan tidak ada yang lebih tinggi dari padanya". Pendapat ini juga disandarkan pada kebolehan dalam al-Quran menikahnya seorang Muslim laki-laki dengan wanita non-Muslimah yang disandarkan pada ayat al-Quran yang telah menghalalkan wanita-wanita nonMuslimah (ahlul kitab) untuk dinikahi orang muslim, akan tetapi mengharamkan wanita-wanita Muslimah untuk menikah dengan lakilaki non-Muslim. ${ }^{15}$

Dengan menelaah landasan hukum yang digunakan oleh Jumhur Ulama, terungkap bahwa dalil yang ada bagi mereka bersifat qathi'y ats-tsubut serta satu-satunya dasar hukum yang tegas dan jelas sehingga memperlihatkan kuatnya hujjah yang mereka gunakan dalam berpendapat dibanding dengan mereka yang menggunakan penalaran.

14 Wahbah Zuhayly, al-Fiqh al-Islamiy wa Adillatuhu, h. 7720.

15 Lanjarto, Wasiat Wajibah bagi Ahli Waris Non-Muslim: Sebuah Upaya Rechtvinding, artikel di dapat dari www.pa-magelang.go.id., h. 7
Namun, dikarenakan ketentuan tersebut tidak diatur dalam al-Quran, melainkan hanya ditetapkan oleh Hadis. Maka rasanya perlu digali lebih mendalam tentang kedudukan hujjah dan Sababul Wurud dari dalil yang mereka gunakan.

Hal ini merupakan upaya penulis dalam menemukan kebenaran teks serta kesesuaiannya dengan konteks pada saat dalil tersebut muncul ke permukaan, agar mendapatkan kejelasan dalam menyelaraskan situasi kekinian yang secara umum berbeda dengan situasi masa lalu di saat diperlukannya dalil tersebut untuk menentukan hukum yang semestinya.

Dilihat dari segi sanadnya, Hadis tersebut berstatus sahih, akan tetapi dari segi matan, Hadis tersebut diragukan kesahihanya. Pertama, karena matan Hadis tersebut, dari beragam redaksinya, menurut satu riwayat dalam Shahih al-Bukhari dan Sunan Ibn Majah ternyata salah satunya adalah pendapat Umar bin Khattab bukan pendapat Nabi Muhammad. ${ }^{16}$

Kedua, daya mengikat Hadis tersebut diragukan karena Mu'adz bin Jabbal pernah memutus kasus harta waris dari pewaris Yahudi yang harta warisannya diberikan kepada ahli waris yang Muslim. Keputusan Mu'adz bin Jabbal tersebut diikuti oleh Yahya bin Ya'mar. ${ }^{17}$

Jika ditelusuri secara historis, teks hadis tersebut lahir (asbabul wurud) dalam konteks permusuhan dengan orang-orang Kafir di masa Islam belum jaya. Yaitu ketika orang-orang kafir

\footnotetext{
${ }^{16}$ Lihat al-Bukhari, Shahih al-Bukhari, h. 438; Ibn Majah, Sunan Ibn Majah, h. 464

17 Lihat Abu Dawud, Sunan Abu Dawud, h. 677 dan 678; dan Imam Hakim, al-Mustadrak 'ala Shahihayn, h. 1523.
} 
Quraisy merampas harta orang-orang Islam yang hijrah ke Madinah.

Kemudian, ketika orang-orang Islam lebih kuat dari mereka, bahkan memenangkan Fath al-Makkah, beberapa dari mereka ingin memperoleh warisan dari sebagian umat Islam. Pada konteks ini, Umar bin Khattab sangat tegas dan keras melarang adanya pewarisan antara orang Islam dan orang kafir. Dari Muslim ke non-Muslim dan dari non-Muslim ke Muslim. 18

Keputusan untuk "tidak ada pewarisan antara muslim dan kafir secara timbal balik" adalah keputusan politik. Begitu juga keputusan untuk "muslim boleh mewarisi kafir dan kafir tidak boleh mewarisi muslim" adalah keputusan politik. Keputusan yang dikeluarkan pada konteks dimana terjadi peperangan dan pembentukan identitas umat Islam.

Saat itu, kafir muncul sebagai istilah yang secara teologis berbeda dengan keyakinan Islam dan secara sosiologis menampakkan (atau berpotensi untuk) permusuhan dan peperangan terhadap umat Islam. Jika pandangan ini bisa diterima, maka waris beda agama, dari kafir untuk muslim atau dari muslim untuk kafir secara timbal balik, bisa dibenarkan sepanjang orang kafir yang dimaksud tidak dalam status permusuhan dan peperangan terhadap umat Islam (Kafir Dzimmi). Bisa dikatakan keputusan status permusuhan dan peperangan ini ada di tangan pemerintah. ${ }^{19}$

18 Tafsir Hadis Jogja, Waris Beda Agama, artikel diakses pada tanggal 10 Desember 2011 dari

http://tafsirhadisjogja.blogdetik.com/2011/12 /10/waris-beda-agama/

19 Tafsir Hadis Jogja, Waris Beda Agama, artikel diakses pada tanggal 10 Desember 2011 dari
Selain pendapat dari para ulama klasik tersebut, ulama-ulama pembaharu (kontemporer) pun seperti Ibnu Hazm, al-Thobari, Muhammad Abduh dan Muhammad Rasyid Ridho memiliki pendapat lain dalam menanggapi permasalahan tersebut.

Selain hanya membolehkan ahli waris Muslim dapat mewarisi pewaris non-Muslim, lebih detil menurut mereka ahli waris non-Muslim dapat memperoleh bagiannya dengan melalui wasiat wajibah. Muhammad Abduh dalam karyanya Tafsir Al-Manar dengan jelas menafsirkan boleh seorang pewaris Muslim mewariskan kepada orang tua dan kerabat yang belum masuk Islam.

Pendapat ini dilandaskan kepada ayat yang mewajibkan seseorang yang kedatangan padanya tanda-tanda maut untuk memberikan wasiat kepada orang tua dan karib kerabatnya, pada surah alBaqarah ayat 180, dan pada hadis Nabi saw.: "Tidak ada wasiat bagi ahli waris" (HR. Ahmad, Abu Dawud dan Tirmidzi) ${ }^{20}$

Dapat dipahami bahwa terkait dengan dalil tentang wasiat di atas, merupakan kewajiban bagi orang-orang yang bertakwa untuk berwasiat atau meninggalkan wasiat kepada orang tua dan kerabatnya secara ma'ruf. Namun, bunyi dalil selanjutnya menyatakan bahwa tidak ada wasiat bagi ahli waris.

Di sinilah letak peran hujjah tersebut dalam menyelesaikan polemik ini, di satu sisi wajib hukumnya memberikan wasiat sebagaimana bunyi ayat di atas, di sisi lain tidak ada wasiat bagi seorang ahli waris. Bila dikaitkan dengan pendapat sebelumnya, Jumhur

http://tafsirhadisjogja.blogdetik.com/2011/12 /10/waris-beda-agama/

20 HR Ahmad (5/267), Abu Dawud dalam kitab al-Washaya, Bab: Mâ Ja`a filWashiyyati lil-Warits (no. 2870), Tirmidzi dalam kitab al-Washaya, Bab: Lâ Washiyyata li Waritsin (no. 2121). 
Ulama menegaskan penghalang ahli waris mendapatkan haknya (salah satunya) adalah berbeda agama.

Jika dikarenakan ahli waris berbeda agama dengan pewaris tidak mendapatkan haknya, sedangkan ayat serta hadis di atas menyatakan bahwa tidak ada wasiat bagi ahli waris padahal wajib memberikan wasiat, maka metode wasiat wajibah merupakan penalaran yang pas untuk menyelesaikan konflik ahli waris non-Muslim.

Sehingga tidak ada larangan bagi seorang pewaris Muslim untuk memberikan wasiatnya kepada ahli waris non-Muslim, bahkan hukumnya wajib bila pewaris meninggalkan harta yang banyak. Di sinilah nalar hukum Muhammad Abduh bermain ketika memosisikan ahli waris non-Muslim untuk mendapatkan haknya melalui wasiat wajibah.

Selain dari pada itu, penulis berpendapat ketika membaca lebih mendetil bunyi ayat tentang kewajiban berwasiat di atas yang dijadikan hujjah oleh Muhammad Abduh dalam menyikapi ahli waris non-Muslim, terdapat sebuah kalimat yang menyatakan bahwa pelaksanaan wasiat dilakukan dengan cara "المعروف".

Hal ini menjadikan penulis teringat bila diartikan atau dikaitkan dengan konsep 'Urf sebagai makna aslinya. Yang melandasi hal tersebut adalah beberapa dasar hukum dalam menjadikan 'Urf sebagai bagian dalam penetapan hukum, seperti: "Dan para wanita mempunyai hak yang seimbang dengan kewajibannya menurut cara yang ma'ruf." (al-Baqarah: 228); "Ambillah secukupnya untuk kamu dan anakmu dengan cara yang ma'ruf (baik)" (HR. alBukhari ${ }^{21}$

21 Lihat al-Bukhari dalam Shahih alBukhari hadits No. 5364 dan penjelasannya dalam Fathul Bari (9/630).
Oleh karenanya, pelaksanaan yang dimaksud dengan "cara yang ma'ruf" sebagaimana makna ayat sebelumnya, maka hal tersebut dikembalikan sesuai dengan kebiasaan atau adat istiadat dan budaya masyarakat setempat. Sebuah kaidah ushul menyatakan bahwa آلْعَادة

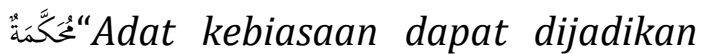
لا يَنْنَرُ ل dasar (pertimbangan) hukum" dan

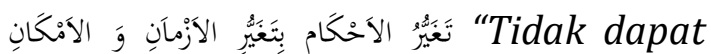
dipungkiri bahwa perubahan hukum (berhubungan) dengan perubahan masa dan tempat".

Dari sudut pandang yang berbeda melalui hukum terapan di Indonesia, baik itu UUD 1945, Kompilasi Hukum Islam dan juga Undang-undang No. 39 Tahun 1999 tentang Hak Asasi Manusia. Dengan dimulai dari penjelasan UndangUndang Dasar 1945 dalam BAB XI tentang Agama pasal 29 ayat 2 bahwa negara menjamin kemerdekaan tiaptiap penduduk untuk memeluk agamanya masing-masing dan untuk beribadat menurut agamanya dan kepercayaannya itu.

Kemudian dengan sangat detil diutarakan dalam BAB XA tentang Hak Asasi Manusia pasal 28I ayat 1 bahwa hak untuk hidup, hak untuk tidak disiksa, hak kemerdekaan pikiran dan hati nurani, hak beragama, hak untuk tidak diperbudak, hak untuk diakui sebagai pribadi di hadapan hukum, dan hak untuk tidak dituntut atas dasar hukum yang berlaku surut adalah hak asasi manusia yang tidak dapat dikurangi dalam keadaan apa pun.

Aturan tersebut menjiwai lahirnya Undang-undang No. 39 Tahun 1999 tentang Hak Asasi Manusia yang dalam salah satu pasalnya menyebutkan dalam pasal 1 ayat 3 bahwa diskriminasi 
adalah setiap pembatasan, pelecehan, atau pengucilan yang langsung ataupun tak langsung didasarkan pada pembedaan manusia atas dasar agama, suku, ras, etnik, kelompok, golongan, status sosial, status ekonomi, jenis kelamin, bahasa, keyakinan politik, yang berakibat pengurangan, penyimpangan, atau penghapusan pengakuan, pelaksanaan, atau penggunaan hak asasi manusia dan kebebasan dasar dalam kehidupan baik individual maupun kolektif dalam bidang politik, ekonomi, hukum, sosial, budaya dan aspek kehidupan lainnya.

Pasal ini didasari atas penjelasan umumnya yang menyatakan bahwa sejarah bangsa Indonesia hingga kini mencatat berbagai penderitaan, kesengsaraan dan kesenjangan sosial, yang disebabkan oleh perilaku tidak adil dan diskriminatif atas dasar etnik, ras, warna kulit, budaya, bahasa, agama, golongan, jenis kelamin dan status sosial lainnya.

Perilaku tidak adil dan diskriminatif tersebut merupakan pelanggaran hak asasi manusia, baik yang bersifat vertikal (dilakukan oleh aparat negara terhadap warga negara atau sebaliknya) maupun horizontal (antar warga negara sendiri) dan tidak sedikit yang masuk dalam kategori pelanggaran hak asasi manusia yang berat (gross violation of human rights).

Islam menjamin akan hal hak kemerdekaan beragama dan berpendirian. Hal di atas sejalan dengan konsep maqashidus syariah dan model berpikir Fiqh Indonesia yang menerapkan bahwa persamaan hak dan kedudukan adalah satu syi'ar yang nyata dalam Islam. Hukum dan ajarannya

\footnotetext{
22 Nourouzzaman Siddiqi, Fiqh Indonesia; Penggagas dan Gagasannya, (Yogyakarta: Pustaka Pelajar, 1997), h. 147
}

adalah penjelmaan dari hak persamaan itu.

Kemerdekaan, perdamaian dan memelihara hak-hak asasi manusia adalah tiang-tiang pancang bagi tegaknya pembangunan dan alat kemajuan suatu negara. Karena itulah, sistem pemerintahan haruslah berasaskan demokrasi yang menjamin hak-hak perorangan dan persamaan. ${ }^{22}$

Dalam pandangan aturan hukum yang lebih spesifik selanjutnya, yang terakumulasi dalam Inpres. No. 1 Tahun 1991 tentang Kompilasi Hukum Islam, mengatur secara tersendiri akan perihal masyarakat Islam Indonesia. Dapat dilihat pada pasal 171 huruf (b) dan (c) yang menyebutkan bahwa pewaris dan ahli waris harus dalam keadaan beragama Islam.

Meski pada pasal 173 perbedaan agama tidak dicantumkan sebagai faktor penghalang praktek mewarisi, pasal 171 huruf (b) dan (c) menyatakan bahwa ahli waris adalah orang yang beragama Islam dan tidak terhalang karena hukum untuk menjadi ahli waris.

Dikarenakan tidak sinkron dan tidak secara jelas inilah menjadi titik lemah dalam aturan yang tertera dalam KHI yang oleh penulis semestinya dengan tegas dan nyata ketika selanjutnya mencantumkan dan menyatakan pada pasal 173 tentang terhalangnya seseorang menjadi ahli waris yang hanya membagi dua kriteria saja yaitu pembunuhan dan fitnah, seharusnya juga memasukkan di dalamnya tentang berbeda agama.

Sehingga wajar dan semestinya dimaklumi bila mana dalam praktek ke depannya hakim mampu melahirkan gebrakan dalam pengembangan dan penemuan hukum baru (upaya 
rechtvinding) dalam kewarisan Islam di Indonesia.

Sedangkan dalam soal wasiat wajibah, KHI mencantumkan dan menerapkan bahwa wasiat wajibah diperuntukkan bagi anak angkat dan orang tua angkat, tidak pada ahli waris yang berbeda agama. Di sinilah menurut penulis hakim berupaya mereinterpretasi aturan tentang wasiat wajibah dalam arti yang lebih luas.

Bahwasanya penerapan wasiat wajibah juga dapat diterapkan bagi ahli waris yang terhalang karena berbeda agama sebab posisinya yang sama-sama terpinggirkan dalam pembagian kewarisan. Maka ia pun layaknya anak angkat yang terhalang menerima waris atau sebagai ahli waris yang sah dari pewaris.

Upaya ini didasari atas pemikiran terhadap metode qiyas yang illat hukumnya sama dengan posisi anak angkat yang sama-sama terhalang mendapatkan waris. Dan untuk menguatkan argumen ini, penulis mendasarkan hal tersebut pada panca jiwa Syariah (maqashidus syariah) yang melindungi segenap hak asasi manusia dari segala kemadharatan serta melahirkan kemaslahatan yang dalam kaidah ushul dinyatakan يزال (kemadharatan harus dihilangkan), hal ini bersumber pada sabda Nabi saw. yang berbunyi: لا ضرر ولا ضرار (tidak boleh memadharatkan diri sendiri dan orang lain).

Jadi intinya putusan Mahkamah Agung yang memberikan wasiat wajibah kepada anak atau kerabat pewaris yang menganut agama selain Islam tidak bertentangan dengan al-Quran, Hadis, Fiqh dan KHI. Putusan ini merupakan putusan yang responsif terhadap isu HAM. Ijtihad yang digunakan adalah

23 Edi Riadi, Dinamika Putusan Mahkamah Agung Republik Indonesia Dalam ijtihad intiqa'i di mana Mahkamah Agung menerapkan hukum yang telah ada bahwa wasiat dapat diberikan kepada orang yang beragama selain Islam. ${ }^{23}$

Dari uraian-uraian di atas, penulis berpendapat baik dari pendekatan ushuliyah maupun hukum terapan di Indonesia, bila dikaitkan dengan konteks keindonesiaan saat ini semestinya praktek wasiat wajibah bagi ahli waris non muslim dapat diterapkan sesuai dengan kasus yang dialami.

Dikarenakan Indonesia di bangun atas dasar empat pilar kebangsaan, yaitu: Pancasila, Undang-Undang Dasar 1945, Negara Kesatuan Republik Indonesia dan Bhineka Tunggal Ika. Sehingga aturan bernegara, berbangsa dan hukumnya pun mesti dilandasi pada asas dan paham yang plural dan demokratis yang tercermin pada empat pilar tersebut. Empat pilar di atas merupakan penentu sekaligus penyangga kehidupan berbangsa dan bernegara.

Ketika melihat keniscayaan fakta dan budaya tersebut, maka polemik tentang ahli waris non-muslim bila ditinjau melalui metode dan model berpikir Fiqh Indonesia sebagai fiqh dengan kepribadian Indonesia. Maka menjadi mungkin bahkan semestinya dapat diterapkan bahwa perbedaan agama bukanlah menjadi salah satu penghalang seseorang mendapatkan haknya ketika melakukan pembagian harta waris melalui wasiat wajibah. Sebuah kaidah fiqhiyyah menyatakan bahwa menemukan hukum baru merupakan keharusan, jika hukum lama tidak memberikan kemaslahatan.

\section{Putusan Nomor 120 K/AG/2005 Tentang Hak Waris Bagi Perkawinan Dibawah Tangan}

Bidang Perdata Islam, (Jakarta: Gramata Publishing, 2011), h. 285 
Yang menjadi problem dalam putusan Nomor 120 K/AG/2005 adalah penerapan tentang terhalangnya para pihak mendapatkan hak waris disebabkan perkawinan di bawah tangan. Hal tersebut tentunya menyalahi aturan hukum, sehingga menjadi landasan kuat majelis hakim dalam memutuskan perkara ini yang dalam amarnya menolak permohonan hak waris dari pihak pemohon sebab perkawinan di bawah tangan.

Hal tersebut terkesan "bertentangan" sebab apa yang diterapkan dan diputuskan hakim berdasarkan kepada bukti autentik berupa pencatatan perkawinan sebagai salah satu penentu sahnya pernikahan, sedangkan aturan hukum Islam selama ini tidak menekankannya sebagai bentuk hilangnya status perkawinan sehingga hilang pula status ahli warisnya.

Pencatatan

merupakan salah satu bentuk pembaruan hukum Islam di Indonesia terutama yang berkaitan dengan hukum keluarga. Dan sejak diberlakukannya pada tahun 1974 melalui Undangundang No. 1 tahun 1974 tentang perkawinan, prosedur legislasi perkawinan masih disalah pahami oleh kebanyakan masyarakat Islam Indonesia. Oleh karenanya terlihat sekali adanya dikotomi antar apa yang dipahami sebagai syarat sahnya perkawinan menurut masyarakat dan pemerintah.

Adapun perkawinan di bawah tangan itu sendiri merupakan perkawinan yang dilakukan menurut fiqh tanpa pencatatan oleh Pegawai Pencatat Nikah (PPN). Dalam hal ini, pencatatan perkawinan merupakan kewajiban administratif bagi warga negara yang melangsungkan perkawinan. dalam suatu negara yang teratur, segala hal yang berhubungan dengan penduduk harus dicatat, seperti kelahiran, kematian, demikian pula perkawinan.

Pencatatan ini selanjutnya dinyatakan dalam surat-surat akta resmi yang dimuat dalam daftar pencatatan. Pencatatan perkawinan sama halnya dengan pencatatan penting dalam kehidupan seseorang seperti adanya akta lahir sebagai tanda bukti kelahiran, Kartu Tanda Penduduk sebagai bukti warga negara, dan lain-lain. Adapun perkawinan berkaitan dengan hak waris mewarisi dan keturunan (al-nasab), sehingga perkawinan harus dicatat untuk menjaga agar jangan sampai ada konflik hukum dikemudian hari.

Dalam hal ini, sahnya suatu akad nikah harus memenuhi ketentuan Undang-undang Perkawinan Pasal 2 ayat (1) mengenai tata cara agama, dan ayat (2) mengenai pencatatan nikahnya oleh Pegawai Pencatat Nikah secara simultan. Dengan demikian, ketentuan ayat (1) dan (2) merupakan syarat kumulatif, bukan syarat alternatif.

Oleh karena itu menurut Undangundang Perkawinan, perkawinan yang dilakukan menurut fiqh Islam tanpa pencatatan oleh Pegawai Pencatat Nikah, belum dianggap sebagai perkawinan yang sah. Dengan demikian bahwa, akta pernikahan tersebut merupakan hal yang sangat menentukan akan kebenaran suatu permasalahan apabila diperkarakan.

Dalam pasal 5 ayat (1) Kompilasi Hukum Islam juga menyebutkan bahwa "agar terjamin ketertiban perkawinan bagi masyarakat Islam setiap perkawinan harus dicatat". Jelas sekali di sini bahwa tujuan utama dari adanya pencatatan perkawinan adalah untuk menciptakan ketertiban yang berkaitan dengan administrasi kenegaraan yang diharapkan akan mengarah kepada terciptanya ketertiban sosial kemasyarakatan. 
Dengan adanya tertib administrasi kenegaraan ini diharapkan peristiwa-peristiwa perkawinan di Indonesia dapat dikontrol sehingga tidak ada pihak-pihak (terutama wanita) yang dirugikan. Dengan kata lain, peraturan perundang-undangan itu dibuat bukannya tanpa tujuan. Seseorang akan mengalami kegagalan untuk mendapatkan kepastian hukum, hanya karena tidak dapat menunjukkan bukti yang autentik tentang identitas pribadi seseorang.

Seperti dalam keluarga, akta perkawinan mempunyai aspek hukum untuk digunakan sebagai bukti jika dalam keluarga terjadi peristiwa kematian, seperti dalam kasus ini. Dengan meninggalkan istri dan beberapa orang anak, yang tampil secara bersama-sama sebagai ahli waris dari si suami (yang meninggal).

Bagaimana caranya untuk membuktikan bahwa ahli waris tersebut adalah istri yang sah dari suaminya yang telah meninggal dunia. Demikian pula bagaimana caranya untuk membuktikan bahwa anak-anak dari hasil pernikahan tersebut benar-benar anak kandung yang sah. Dalam hal ini, tidak akan timbul kesulitan apabila telah memiliki bukti autentik berupa akta perkawinan yang dibuat oleh pejabat yang berwenang.

Dengan demikian, tidak ada alasan sama sekali sesungguhnya yang menghalangi proses pencatatan perkawinan di Indonesia. Lebih tegasnya lagi adalah, bahwa peristiwa nikah di bawah tangan adalah peristiwa yang ilegal yang tidak dapat dipertanggungjawabkan di hadapan hukum.

Oleh karenanya, bila pernikahan di bawah tangan, alias nikah tanpa surat nikah dianggap legal selama ini, tentunya dapat menimbulkan fitnah di mana-mana jika seseorang berjalan dengan seorang wanita yang bukan muhrimnya. Lebih tegasnya lagi adalah, akan muncul praktek prostitusi dengan alasan nikah siri atau nikah di bawah tangan ini.

Yang menjadi masalah sekarang adalah, tentang status pencatatan pernikahan dalam rukun nikah menurut hukum Islam. Mazhab Syafi'i (yang menjadi pegangan mayoritas muslim Indonesia dan diakomodasi dalam pasal 14 Kompilasi Hukum Islam) rukun perkawinan ada lima, yaitu calon suami, calon istri, wali, dua orang saksi dan ijab qabul.

Hal tersebut menunjukkan, bahwa peraturan pencatatan pernikahan tidak pernah ada di dalam kitab-kitab fiqh klasik, itu berarti pencatatan pernikahan bertentangan dengan hukum Islam. Dikarenakan bertentangan maka tidak ada konsekuensi agama apa pun apabila mereka meninggalkannya. Sederhananya, ketentuan pencatatan pernikahan itu hanyalah masalah administrasi negara saja dan tidak ada hubungannya dengan kategori sah atau tidaknya sebuah perkawinan.

Untuk itu, selain dari aturanaturan hukum terapan yang telah tercantum dalam Undang-undang di Indonesia seperti yang dijelaskan di atas. Penulis akan menganalisis pula melalui tiga pendekatan yang jernih dan rasional seperti yang terdapat dan diterapkan dalam model bepikir Fiqh Indonesia.

\section{a. Pendekatan Historis (tarikh tasyri')}

Mengapa dalam kitab-kitab fiqh klasik tidak menyebutkan tentang pencatatan perkawinan? hal tersebut dikarenakan pada waktu kitab-kitab fiqh itu ditulis tingkat amanah kaum muslimin relatif tinggi. Sehingga kemungkinan menyalahgunakan lembaga perkawinan untuk tujuan sesaat atau sementara yang tidak sejalan 
dengan tujuan ideal perkawinan dan merugikan pihak lain relatif kecil. Pernyataan ini tentunya tidak dimaksudkan menggeneralisir bahwa sekarang ini tingkat amanah masyarakat itu sudah luntur.

b. Pendekatan Kaidah Fiqh adalah:

Kaidah yang penulis gunakan

Artinya: "Tidak sempurna suatu kewajiban kecuali dengan sesuatu, maka adanya sesuatu itu menjadi wajib hukumnya."

Berkaitan dengan penggunaan kaidah ini pada kasus pencatatan perkawinan, penulis berangkat dari anggapan bahwa pencatatan perkawinan adalah satu peraturan yang sengaja dibuat dalam rangka menyempurnakan kualitas sebuah pernikahan.

Penyempurnaan

kualitas pernikahan ini berkaitan erat dengan status pernikahan yang merupakan bagian dari perintah Allah swt. dalam rangka beribadah kepada-Nya. Karena tujuannya yang luhur itu, maka segala peraturan yang telah ada sebelumnya dalam kitab-kitab fiqh klasik dan peraturan yang muncul kemudian wajib untuk diadakan.

Dengan demikian, berlakulah ketentuan kaidah di atas bahwa tidak sempurna suatu kewajiban kecuali dengan sesuatu, maka adanya sesuatu itu menjadi wajib hukumnya. Artinya, tidak sempurna sebuah pernikahan kecuali dengan adanya pencatatan, maka adanya pencatatan menjadi wajib hukumnya.

\section{c. Pendekatan Maslahat}

Pendekatan ini muncul sebagai jawaban bahwa nikah di bawah tangan atau tanpa pencatatan dari Petugas Pencatat Nikah adalah sah menurut agama. Menurut hemat penulis, perkawinan tersebut sah menurut fiqh karena fiqh merupakan hasil interpretasi para ulama (ijtihad) yang harus selalu disesuaikan dengan perubahan zaman, tempat dan keadaan, tapi tidak atau belum sah menurut agama, karena agama memiliki aturan hukum berupa kemaslahatan, dengan artian bahwa sesuatu yang maslahat pada masa dahulu dan di tempat yang berbeda (yakni di Timur Tengah), belum tentu maslahat pada masa sekarang khususnya di Indonesia.

Hal ini dikarenakan bahwa pesan yang dibawa oleh agama adalah universal di bawah prinsip rahmatan lil 'alamin. Artinya, segala tindakan manusia hanya dapat dibenarkan menggunakan justifikasi agama sejauh ia mendatangkan manfaat bagi kepentingan umum (li tahqiq mashalih al-'ammah), bukan kemaslahatan yang bersifat perorangan atau kasuistik.

Ini berbeda dengan fiqh yang diformulasikan oleh fuqaha' yang dipengaruhi oleh ruang dan waktu. Jadi, bisa saja pendapat seorang ulama dahulu mendatangkan kemaslahatan pada masanya, namun diterapkan dalam kondisi sekarang akan menimbulkan kemadharatan.

Oleh karena itu, harus dibedakan dan tidak dipertentangkan. Apalagi jika yang didukung menimbulkan kesengsaraan bagi pihak istri yang ditinggalkan suaminya tanpa tanggung jawab yang jelas. Maka, dalam hal ini penulis jelaskan bahwa bukannya masalah ini tidak relevan dengan Nash dan fiqh, tetapi kesalahan itu berada pada penempatan yang kurang tepat dengan kepentingan saat ini.

Berdasarkan penjelasan di atas, sangatlah jelas bahwa pencatatan pernikahan merupakan produk Fiqh Indonesia. Bila masyarakat Indonesia saat ini masih melakukan praktik pernikahan di bawah tangan maka ia 
sama saja menyalahi aturan Fiqh Indonesia.

Sebab seiring dengan perkembangan dan kebutuhan yang ada dalam konteks ke-Indonesiaan, maka rukun perkawinan di Indonesia tidak hanya lima syarat, sebagaimana telah disinggung sebelumnya. Akan tetapi, jumlahnya bisa menjadi enam, yakni ditambah dengan ketentuan pencatatan pernikahan yang dilakukan oleh petugas yang berwenang menurut peraturan perundang-undangan. Dan ini menjadi kewajiban mutlak bagi masyarakat Indonesia yang hendak melaksanakan perkawinannya di Indonesia.

\section{Kesimpulan}

Fiqh Indonesia adalah produk anak zaman yang lahir sebagai jawaban konkret atas kebutuhan masyarakat Indonesia yang secara kultural, struktur sosial dan prilaku masyarakatnya memiliki ciri yang khas terhadap problematika masyarakatnya. Oleh karenanya, sebagai sebuah teori dan nomenklatur tentunya ia dapat berdaya guna dalam melahirkan jawaban yang berkemaslahatan bagi masyarakat pada umumnya.

Sehingga ketika ada permasalahan arus global yang jawabannya secara tekstual tidak terakomodir dalam sumber hukum yang ada, maka sebagai sebuah pemahaman yang menekankan pada kultur budaya dan pemahaman akan keindonesiaan dapat terealisir dalam jawaban yang sesuai dengan kemaslahatan bagi masyarakat Indonesia.

Mahkamah Agung adalah sebuah lembaga negara tertinggi yang salah satu perannya menjawab permasalahan yang diajukan olehnya di tingkat kasasi, salah satunya terkait dengan masalah perdata agama yang kemaslahatannya sering berubah-ubah. Dari ketiga putusan yang penulis analisa kaitannya dengan perdata agama ditemukan, yang sangat ditekankan dalam dasar pertimbangannya; (1) soal kasus ahli waris non muslim bahwa dengan melandaskan kepada al-Quran surah alBaqarah ayat 180 dan pendapat Ibnu Hazm tidak ada larangan bagi ahli waris yang non muslim untuk menerima wasiat wajibah; dan (2) tentang terhalangnya mendapatkan hak waris dari pernikahan yang tidak dicatatkan, ditekankan bahwa yang menjadi syarat sah pernikahan adalah pencatatan pernikahan sebagaimana yang tertera dalam undang-undang, sehingga akibat apapun setelah pernikahan yang tidak dicatatkan maka dianggap ilegal termasuk tuntutan waris.

Berdasarkan kedua putusan yang dianalisa, diketahuilah selama ini pendekatan yang dianut oleh para hakim dalam menelaah dan menyelesaikan berbagai macam masalah. Yaitu, pendekatan sosio-cultural yang terakomodir dalam konstruk berpikir Fiqh Indonesia.

Seperti kasus ahli waris nonmuslim yang mendapatkan haknya melalui jalur wasiat wajibah, keputusan ini tidak terlepas akan isu HAM dan prinsip pluralitas kehidupan bangsa Indonesia yang bhineka tunggal ika, dan dari kasus pernikahan yang tidak dicatatkan menjadikan akta nikah sebagai perwujudan dari budaya administratif bangsa Indonesia sejak zaman pembangunan yang menghendaki pelaksanaannya sebagai sebuah kewajiban yang harus dilaksanakan dan ditaati sebagai sebuah rukun bagi setiap kalangan yang hendak menikah.

Kesemua hal tersebut, membuat penulis teringat di saat sesi wawancara penulis pada salah satu hakim agung yang mengamini tentang statement penulis bahwa pola pemahaman hakim 
tentu tidak akan terlepas dari konstruk berpikir Fiqh Indonesia dalam memecahkan kasus-kasus umat Islam, sebab dari situlah inspirasi datang sebagai penyelesaian problematika kekinian.

\section{DAFTAR PUSTAKA}

Abdullah, Abdul Gani. Pegantar Kompilasi Hukum Islam Dalam Tata Hukum Indonesia, Jakarta: Gema Insani Press, 1994.

Departemen Agama RI. Al-Quran dan Terjemahnya, Semarang: PT. Karya Toha Putra, 1998.

Erfani. Spesifikasi Putusnya Perkawinan Karena Perceraian: Upaya Modifikasi Penerapan Hukum Putusnya Perkawinan karena Perceraian di Pengadilan Agama, makalah ini dibuat pada tanggal 30 Desember 2011.

Fuad, Mahsun. Hukum Islam Indonesia; Dari Nalar Partisipatoris Hingga Emansipatoris, Yogyakarta: LKiS, 2005.

Lanjarto. Wasiat Wajibah bagi Ahli Waris Non Muslim: Sebuah Upaya Rechtvinding, artikel di dapat dari www.pa-magelang.go.id.

Muhammad, Husein, dkk. Dawrah Fiqh Concering Women-Modul Kursus Islam dan Gender, Cirebon: Fahmina Institute, 2007.

Munthe, Abdul Karim. Hukum Islam dan Perubahan Masyarakat, diakses pada tanggal 29 Januari 2014 dari http://abdulkarim

munthe.blogspot.com/2013/02/hu kum islam dan perubahan masyarakat

Rajafi, Ahmad., Nalar Hukum Keluarga Islam di Indonesia, Yogyakarta: Istana Publishing, 2015
------, "Sejarah Pembentukan dan Pembaruan Hukum Keluarga Islam di Nusantara", Aqlam: Journal of Islam and Plurality, Vol. 2, No. 1, Desember 2017

, The Renewal Movement of Islamic Family Law In Indonesia (Politics of Islamic Law from Old Order until Reformation), Proceeding, 1st Biennial Conference on Sharia and Social Studies, Fakultas Syari'ah UIN Padang, 2017

Riadi, Edi, Dinamika Putusan Mahkamah Agung Republik Indonesia Dalam Bidang Perdata Islam, Jakarta: Gramata Publishing, 2011.

Sahriani, Thesis: Pembagian Harta Warisan Orang Yang Berbeda Agama Dalam Perspektif Hukum Islam (Studi Kasus Putusan Mahkamah Agung RI No. 51 $K / A G / 1999)$, Sekolah Pascasarjana Universitas Sumatra Utara, Medan, 2009.

Siddiqi, Nourouzzaman, Fiqh Indonesia: Penggagas dan Gagasannya, Yogyakarta: Pustaka Pelajar, 1997.

Tafsir Hadis Jogja, Waris Beda Agama, artikel diakses pada tanggal 10 Desember 2011 dari http://tafsirhadisjogja.blogdetik.co $\mathrm{m} / 2011 / 12 / 10 /$ waris-bedaagama/

Wahid, Marzuki, Fiqh Indonesia: Kompilasi Hukum Islam dan Counter Legal Draft Kompilasi Hukum Islam dalam Bingkai Politik Hukum Indonesia, Bandung: Marja, 2014. 